\title{
Studies on Various Concentrations of Antioxidants with Alkaline Emulsion of Ethyl Oleate as Pre-Treatment on Rate of Drying, Yield and Colour of Raisins Prepared from Seedless Grape (Vitis vinifera $\mathbf{L}$.)
}

\section{A. Venkatram ${ }^{1 *}$, A.S. Padmavathamma ${ }^{1}$, D. Vijaya ${ }^{2}$, A. Siva Sankar ${ }^{3}$, K. Manorama ${ }^{4}$ and B. Srinivas Rao ${ }^{2}$}

${ }^{1}$ Department of Fruit Science, Dr. Y.S.R. Horticultural University, Hyderabad, Telangana, India

${ }^{2}$ Grape Research Station, Rajendranagar, Hyderabad, Telangana, India

${ }^{3}$ Department of Crop Physiology, Acharya N.G. Ranga Agricultural University,

Hyderabad, Telangana, India

${ }^{4}$ Quality Control Laboratory, Professor Jayashankar Telangana State Agricultural University,

Hyderabad, Telangana, India

*Corresponding author

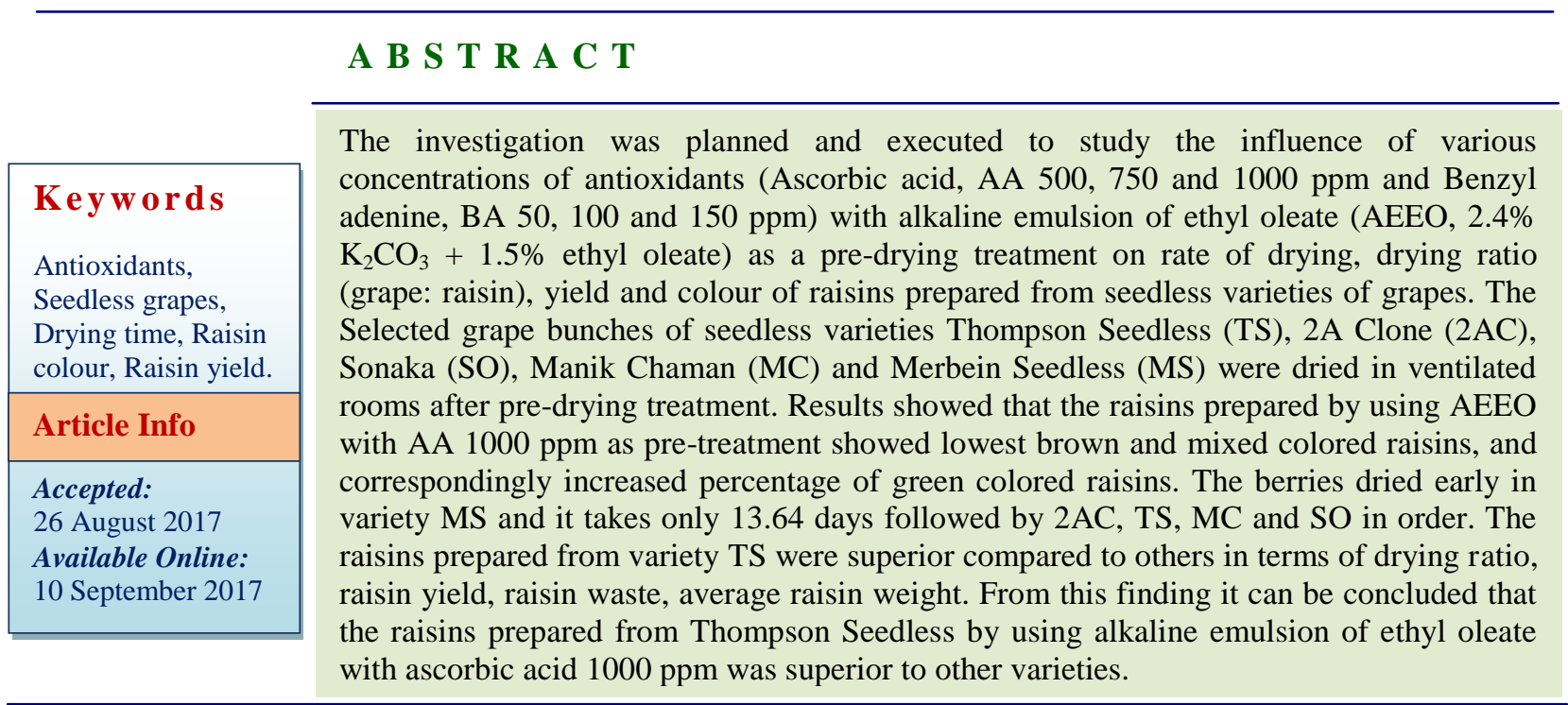

\section{Introduction}

Grape (Vitis vinifera L.) is an important commercial fruit crop in India, about $78 \%$ of production is used for table purpose; nearly 17 to $20 \%$ is dried for raisin production, while $1.5 \%$ is used for juice and only $0.5 \%$ is used in manufacturing wine. Dried grapes, commonly known as raisins, are of a great economic importance for many countries.
Raisins are a good source of fiber, $\mathrm{K}, \mathrm{Fe}, \mathrm{Ca}$ and vitamin $\mathrm{B}$ and are free from fat and cholesterol. They contain only natural sugars as a source of energy. The word 'raisin' originates from the French word 'racemes', which means 'a cluster of grapes or berries'. Historically the production of raisin from grapes by sun-drying can be traced back to 
1490 B.C. in Greece (Winkler, 1962). USA, Turkey, China, Iran, Chile, Argentina, Australia and Greece are the main raisins producers in the world (DFTS, 2013). In India, raisins are mainly produced in Sangli, Solapur and Nasik districts of Maharashtra and Bijapur district of Karnataka state from the varieties viz., Thompson Seedless and its clones like Tas-A-Ganesh, Sonaka and Manik Chaman (Adsule et al., 2008). Telangana State falls under semi-arid tropical region wherein the major grape cultivation is confined to Ranga Reddy, Mahabubnagar and parts of Nalgonda district. Since the harvest period (February to May) is during summer with low relative humidity, it is excellent for raisin making. The different varieties of seedless grapes grown here are vigorous and highly productive.

The varied physical characteristics of raisins are probably the result of cultivars, cultural practice followed and processing differences. The technique of raisin production in India is mostly based on the dipping of the grape bunches in emulsion having $2.5 \%$ potassium carbonate and $1.5 \%$ ethyl oleate for a duration of 2 to 4 minutes, and subsequent shade drying in open tier system (Adsule et al., 2012). The dipping oil treatment alone induced soft texture, but it led to the development of brown rather greenish color. Green coloured raisins are highly valued for their fresh, attractive green color, sweet flavour and sold for two to three times the price of sun-dried raisins.

Antioxidants are the molecules that are capable of preventing the oxidation of other molecules by scavenging reactive oxygen species before they can damage the cells. Application of antioxidants like ascorbic acid and benzyl adenine along with dipping solution i.e. alkaline emulsion of ethyl oleate (AEEO, 2.4\% $\mathrm{K}_{2} \mathrm{CO}_{3}+1.5 \%$ ethyl oleate) as a pretreatment effectively reduced browning in raisins (Sharma et al., 2012). Green color retention is one of the major concerns in raisin production; hence, the study was carried out to find the effect of various concentrations of antioxidants on drying, colour and yield of raisins prepared from various seedless varieties of grapes.

\section{Materials and Methods}

The experiment was conducted at Grape Research Station, Rajendranagar, Hyderabad in Ranga Reddy district, Dr. Y.S.R. Horticultural University during 2012-14. The Grape Research Station is located at $77^{\circ} 85^{\prime}$ East longitude and $18^{\circ} 45^{\prime}$ North latitude and at an altitude of $542.6 \mathrm{~m}$ above mean sea level. The experimental location falls under semi-arid tropical climatic zone, having annual rainfall of $800 \mathrm{~mm}$.

Selected grape bunches of seedless varieties $\left(\mathrm{V}_{1}\right)$ Thompson Seedless (TS), $\left(\mathrm{V}_{2}\right)$ 2A Clone (2AC), $\left(\mathrm{V}_{3}\right)$ Sonaka (SO), $\left(\mathrm{V}_{4}\right)$ Manik Chaman $(\mathrm{MC})$ and $\left(\mathrm{V}_{5}\right)$ Merbein Seedless (MS) were manually harvested. The harvested bunches were cleaned, washed in soap water followed by washing in pure water. A solution containing $2.4 \%$ potassium carbonate $+1.5 \%$ ethyloleate (i.e. alkaline emulsion of ethyl oleate, AEEO) was prepared in a plastic bucket. The $\mathrm{pH}$ of the solution was adjusted to 11 while adding potassium carbonate. Dipping solutions of $500 \mathrm{ppm}, 750 \mathrm{ppm}$ and $1000 \mathrm{ppm}$ of ascorbic acid (AA) were prepared by dissolving $5 \mathrm{~g}, 7.5 \mathrm{~g}$ and $10 \mathrm{~g}$ of AA respectively in 10 litres of AEEO. Similarly $50 \mathrm{ppm}, 100 \mathrm{ppm}$ and $150 \mathrm{ppm}$ of benzyl adenine (BA) were prepared by dissolving $0.5 \mathrm{~g}, 1 \mathrm{~g}$ and $1.5 \mathrm{~g}$ of $\mathrm{BA}$ respectively in 10 litres of AEEO. Then the grape bunches were dipped in the solution prepared for dipping i.e. $\left(\mathrm{A}_{1}\right) \mathrm{AEEO}+\mathrm{AA}$ $500 \mathrm{ppm},\left(\mathrm{A}_{2}\right) \mathrm{AEEO}+\mathrm{AA} 750 \mathrm{ppm},\left(\mathrm{A}_{3}\right)$ $\mathrm{AEEO}+\mathrm{AA} 1000 \mathrm{ppm},\left(\mathrm{A}_{4}\right) \mathrm{AEEO}+\mathrm{BA} 50$ ppm, ( $\left.\mathrm{A}_{5}\right) \mathrm{AEEO}+\mathrm{BA} 100 \mathrm{ppm},\left(\mathrm{A}_{6}\right)$ AEEO $+\mathrm{BA} 150 \mathrm{ppm}$ and $\left(\mathrm{A}_{7}\right)$ AEEO as a control for 3 minutes, and then kept for shade drying 
in trays. Under shade drying, the trays of pretreated bunches were placed in well ventilated room at ambient condition. Moisture testing of raisins was done frequently for a preserved level (approximately 15\% moisture).

After imposition of pre-treatments, the weight of the grapes in each replication was recorded every three days intervals. The rate of drying was obtained by loss of moisture during the drying period (Sharma et al., 2013). The time taken for drying (in days) for pre-treated grapes were calculated when the moisture level in raisins comes to 15 per cent (Parpinello et al., 2012). Drying ratio calculated by the weight of fresh grape to obtained raisins. The weight of 100 raisins of each replication was taken and calculated to obtain average weight of raisins (Adsule et $a l ., 2008)$. Raisin yield recorded in kilo gram of raisins per vine (Parpinello et al., 2012). The weight of decayed, over shrivelled and damaged raisins was taken and calculated to grams of raisin waste from fresh grapes. The prepared raisins were graded based on color i.e. pale green (consider as green in the entire experimentation), brown and mixed (the mixture in which the percentage of dominant color did not exceed $60 \%$ ). Hundred grams of raisins was weighed and the separation of which was done according to the mentioned color classes (Arzani et al., 2009).

The experimental data were subjected to analysis of variance (ANOVA) using factorial completely randomized design as per the procedure out lined by Panse and Sukhatme (1985). Least significant differences (Fisher's protected LSD) were calculated following significant F-test $(\mathrm{p}=0.05)$.

\section{Results and Discussion}

\section{Rate of drying}

The rate of drying was significantly different from the various concentrations of antioxidants with alkaline emulsion of ethyl oleate (AEEO) during drying period. It was evident from figure 1 that the increased concentrations of antioxidants (i.e. Ascorbic acid, AA and Benzyl adenine, BA) with AEEO decreases water loss on $3^{\text {rd }}, 6^{\text {th }}, 9^{\text {th }}$, $12^{\text {th }}$ and $15^{\text {th }}$ days after pre-treatment. Various concentrations of antioxidants with AEEO significantly fastened the water loss from the berries on all the days (day 3 to day 15) after pre-drying treatment. Significantly maximum water loss was recorded in AEEO + AA 1000 ppm and minimum in control (i.e. AEEO only) during the drying period. The rate of drying was faster in pre-drying treatment $\mathrm{A}_{3}$ in our study which might be due to the ascorbic acid pre-treatment tends to loosen the water molecules (Abano et al., 2013). Grncarevic (1963) and Bingol et al., (2012) also found that the grapes treated with a cold dip of commercial dipping oil (ethyl oleate + $\mathrm{K}_{2} \mathrm{CO}_{3}$ ) enhance the drying rates.

On day 3 and 6, significantly maximum water loss was recorded in Merbein Seedless and minimum in Sonaka (Figure 2). On day 15, it was noted highest in Merbein Seedless and lowest in Sonaka which was comparable with Manik Chaman. In all the days after predrying, there wasn't much oscillation between the values of water loss in different varieties of grapes used for raisin making (Figure 2). Comparatively, Merbein Seedless berries were smallest and thin skin which might be the result of early drying compared to other varieties (Chadha and Shikhamany, 1999). The water loss in Sonaka was lower which might be due to more juicer, less pulpy and bigger size berries compared to other varieties. As mentioned earlier, Ramming (2009) and Christensen and Peacock (2000) also observed differences in drying rate between the cultivars and suggested that cultivar differences in berry cuticle and skin influence drying rate. The interaction effect on water loss between various concentrations of antioxidants with AEEO and varieties was 
not significant in all the days after pre-drying treatment.

\section{Drying ratio (grape: raisin)}

The results related to drying ratio (fresh grapes to obtained raisins) as influenced by various concentrations of antioxidants with AEEO as pre-drying treatment in seedless grape varieties are depicted in table 1. A minimum of $3.99 \mathrm{~kg}$ of fresh grapes were required to obtain $1 \mathrm{~kg}$ raisins in pre-drying treatment AEEO + AA $1000 \mathrm{ppm}\left(\mathrm{A}_{3}\right)$ whereas a maximum of $4.18 \mathrm{~kg}$ was required to obtain same amount of raisins in control $\left(\mathrm{A}_{7}\right)$. It was recorded to be lowest in $\left(\mathrm{A}_{3}\right)$ which may be due to the ascorbic acid play major role in drying (Figure 1) which ultimately leads to lower drying ratio (Farouk, 2011). The drying ratio also significantly influenced by grape varieties used for raisin making. It was significantly lowest in Thompson Seedless (3.87) whereas Merbein Seedless (4.33) recorded maximum. The interaction effect on drying ratio between pretreatment and varieties was not significant. Thompson Seedless variety showed lowest drying ratio which might be due to high total soluble solids and sugars accumulation in fresh berries as reported by Christensen and Peacock (2000). Jadhav et al., (2010) also found that, pre-drying with $1.5 \%$ olive oil + $6 \% \mathrm{~K}_{2} \mathrm{CO}_{3}$ for $3 \mathrm{~min}$. dipping at $42^{\circ} \mathrm{C}$ recorded the lowest dehydration ratio in Thompson Seedless grapes.

\section{Drying time (days)}

It was evident from table 1 , significantly lowest drying time of 14.21 days was recorded in AEEO + AA 1000 ppm $\left(\mathrm{A}_{3}\right)$, whereas it was maximum in control (15.17 days), which might be due to high water loss (Figure 1) in present study. The time required for drying was lowest in AEEO either with AA or BA irrespective of their concentration compared with control. Regarding varieties,
Merbein Seedless berries dried quicker (13.64 days) and Sonaka takes more time (14.99 days) for drying (Figure 2). The drying time of Manik Chaman (14.85 days) and Thompson seedless (14.80 days) were comparable with each other. The shortest drying time was recorded in Merbein Seedless followed by 2A Clone, Thompson Seedless, Manik Chaman and Sonaka in order due to various rate of drying (Figure 2) in this study. The interaction effect on drying time between pre-treatment and varieties are not significant.

\section{Average raisin weight (g)}

Significantly the highest raisin weight was noted in pre-treatment $\mathrm{A}_{3}(0.474 \mathrm{~g})$ whereas it was lowest recorded in untreated berries $(0.463 \mathrm{~g})$. It was observed that there was no significant difference among the various concentrations of AA (500, 750 and 1000 ppm) as well as BA (50, 100 and $150 \mathrm{ppm})$ with AEEO as a pre-treatment on average raisin weight. Sonaka raisin recorded a maximum of $0.504 \mathrm{~g}$, which was on par with Manik Chaman $(0.501 \mathrm{~g})$ whereas it was lowest in variety Merbein Seedless $(0.426 \mathrm{~g})$ in the present study could be due to the high moisture content in raisins (Ramming, 2009).

The interaction between pre-treatment and varieties was not significant. In our study the highest raisin weight was recorded in predrying treatment AEEO + AA $1000 \mathrm{ppm}\left(\mathrm{A}_{3}\right)$ which may be due to highest water loss (Figure 1) in the berries during drying period, which leads to higher raisin weight (Figure 1). Adsule et al., (2008) also reported that the raisins prepared by dipping oil method in seedless grape varieties recorded raisin weight from 0.34 to $0.45 \mathrm{~g}$.

\section{Raisin yield (kg/vine)}

It was evident from data, there was significant difference $(p=0.05)$ found among the treatments and varieties on raisin yield. The 
maximum and on par raisin yield was recorded in $\mathrm{A}_{3}$ (4.81 kg/vine), $\mathrm{A}_{2}$ (4.71 $\mathrm{kg} / \mathrm{vine})$ and $\mathrm{A}_{1}(4.70 \mathrm{~kg} / \mathrm{vine})$. The highest raisin yield was recorded in pre-drying treatment AEEO + AA $1000 \mathrm{ppm}\left(\mathrm{A}_{3}\right)$ which may be due to the lowest raisin waste and highest average raisin weight (Table 1) was recorded in this treatment because the ascorbic acid play major role to terminate radical chain reactions ultimately leads to higher raisin yield (Davey et al., 2000 and Farouk, 2011). The yield was recorded maximum in Thompson Seedless which might be due to its high total soluble solids and sugars in fresh berries corresponding increase in raisin yield. Obviously, Winkler (1962) and Jadhav et al., (2010) also reported that greater the rate of sugars in fresh grapes, greater will be the raisin yield, which may be relatively the same for present studied varieties.

Fig.1 Rate of drying (per cent water loss during drying period) of grapes as affected by various concentrations of antioxidants with alkaline emulsion of ethyl oleate as a pre-drying treatment

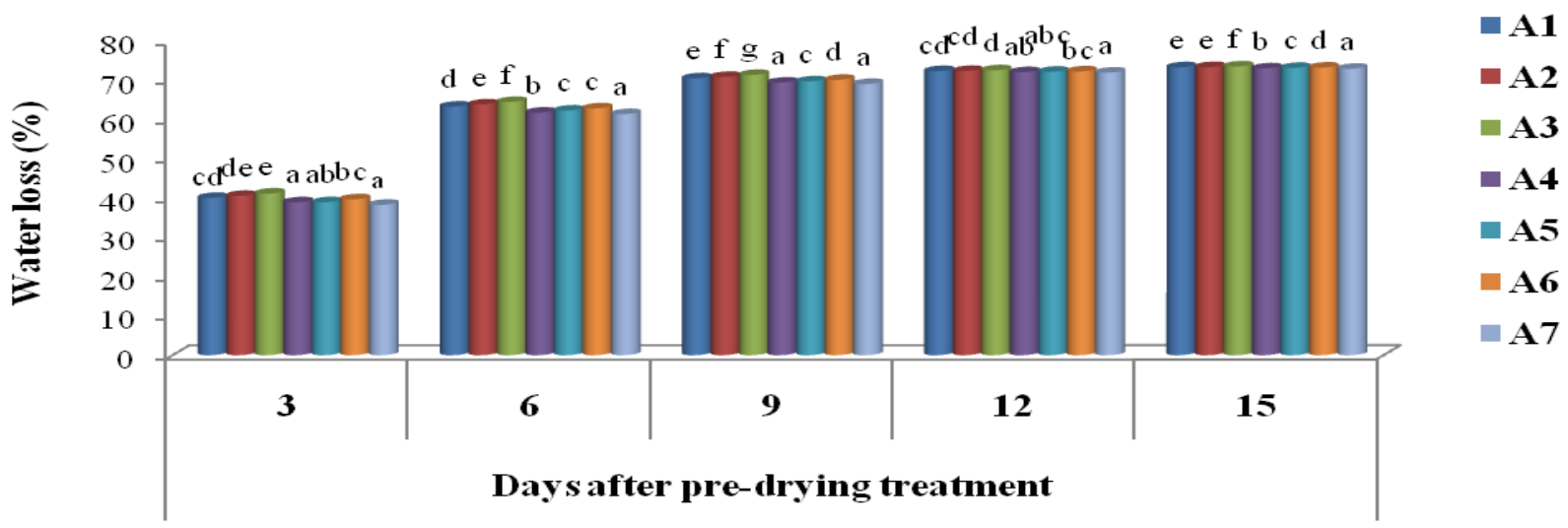

Bars labelled with the same alphabets on each days after pre-drying treatment were not significantly different at $\mathrm{p} \leq 0.05$.

Fig.2 Rate of drying (per cent water loss during drying period) of seedless grape varieties after pre-drying treatment

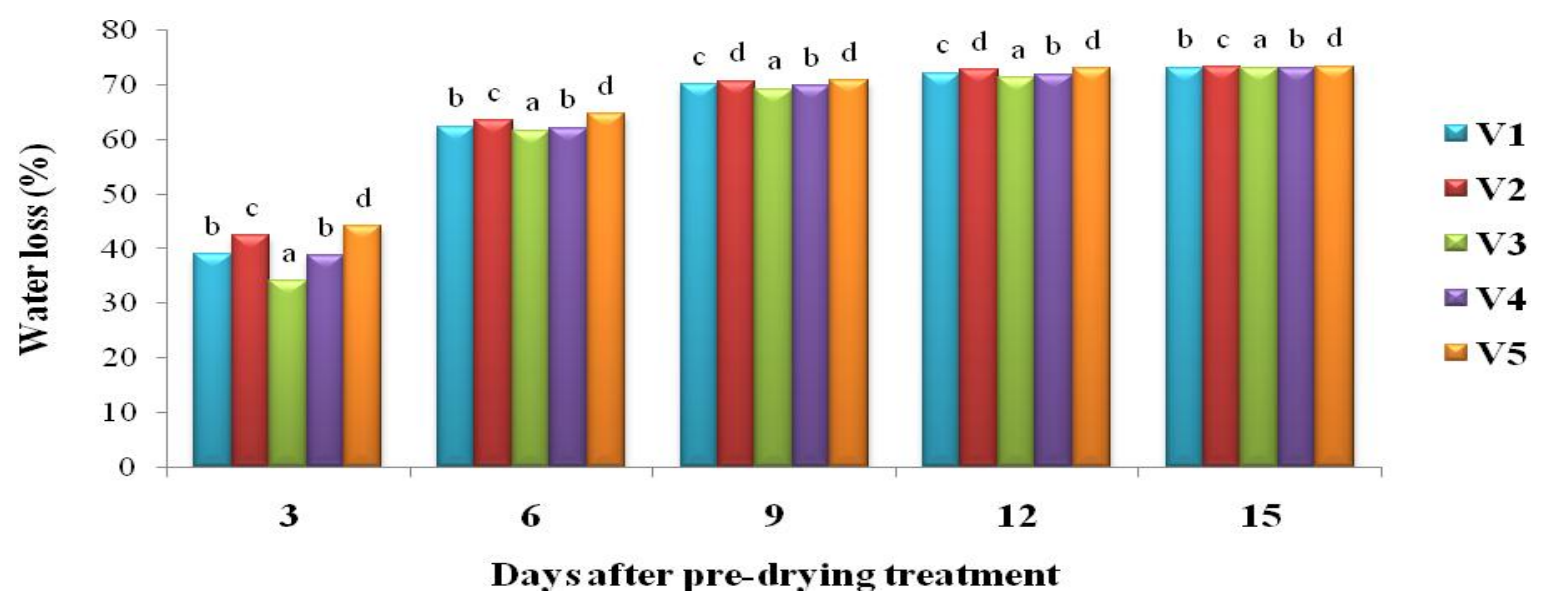

Bars labelled with the same alphabets within varieties on each day after pre-drying treatment were not significantly different at $\mathrm{p} \leq 0.05$. 
Table.1 Effect of various concentrations of antioxidants with alkaline emulsion of ethyl oleate (AEEO) as a pre-drying treatment on drying time, drying ratio (fresh grape to raisin), average raisin weight, raisin yield, raisins wastes and percentage of green, brown and mixed colored raisins prepared from seedless varieties of grapes

\begin{tabular}{|c|c|c|c|c|c|c|c|c|}
\hline \multirow{2}{*}{ Pre-drying treatments (A) } & \multirow{2}{*}{$\begin{array}{c}\text { Drying } \\
\text { time } \\
\text { (days) }\end{array}$} & \multirow{2}{*}{$\begin{array}{l}\text { Drying } \\
\text { ratio } \\
\text { (grape to } \\
\text { raisin) }\end{array}$} & \multirow{2}{*}{$\begin{array}{c}\text { Average } \\
\text { raisin } \\
\text { weight (g) }\end{array}$} & \multirow{2}{*}{$\begin{array}{l}\text { Raisin yield } \\
\text { (kg/vine) }\end{array}$} & \multirow{2}{*}{$\begin{array}{c}\text { Raisin } \\
\text { wastes (g) }\end{array}$} & \multicolumn{3}{|c|}{ Percentage of colored raisins } \\
\hline & & & & & & Green & Brown & Mixed \\
\hline $\mathrm{A}_{1}-\mathrm{AEEO}+\mathrm{AA} 500 \mathrm{ppm}$ & $14.34^{\mathrm{ab}}$ & $4.09^{\mathrm{b}}$ & $0.470^{\mathrm{ab}}$ & $4.70^{\mathrm{ab}}$ & $102.50^{\mathrm{bc}}$ & $70.52^{\mathrm{b}}$ & $9.78^{\mathrm{ab}}$ & $19.70^{\mathrm{b}}$ \\
\hline $\mathrm{A}_{2}-\mathrm{AEEO}+\mathrm{AA} 750 \mathrm{ppm}$ & $14.27^{\mathrm{ab}}$ & $4.07^{\mathrm{ab}}$ & $0.473^{\mathrm{a}}$ & $4.71^{\mathrm{ab}}$ & $100.90^{\mathrm{ab}}$ & $71.05^{\mathrm{b}}$ & $9.62^{\mathrm{ab}}$ & $19.33^{\mathrm{ab}}$ \\
\hline $\mathrm{A}_{3}-\mathrm{AEEO}+\mathrm{AA} 1000 \mathrm{ppm}$ & $14.21^{\mathrm{a}}$ & $3.99^{\mathrm{a}}$ & $0.474^{\mathrm{a}}$ & $4.81^{\mathrm{a}}$ & $99.30^{\mathrm{a}}$ & $72.28^{\mathrm{a}}$ & $8.64^{\mathrm{a}}$ & $19.08^{\mathrm{a}}$ \\
\hline $\mathrm{A}_{4}-\mathrm{AEEO}+\mathrm{BA} 50 \mathrm{ppm}$ & $14.47^{\mathrm{b}}$ & $4.15^{\mathrm{b}}$ & $0.467^{\mathrm{bc}}$ & $4.59^{\mathrm{bc}}$ & $105.05^{\mathrm{de}}$ & $67.70^{\mathrm{d}}$ & $10.62^{b}$ & $21.68^{\mathrm{d}}$ \\
\hline $\mathrm{A}_{5}-\mathrm{AEEO}+\mathrm{BA} 100 \mathrm{ppm}$ & $14.44^{\mathrm{b}}$ & $4.14^{\mathrm{b}}$ & $0.467^{\mathrm{bc}}$ & $4.60^{\mathrm{bc}}$ & $103.60^{\mathrm{cd}}$ & $68.27^{\mathrm{cd}}$ & $10.22^{\mathrm{b}}$ & $21.51^{\mathrm{cd}}$ \\
\hline $\mathrm{A}_{6}-\mathrm{AEEO}+\mathrm{BA} 150 \mathrm{ppm}$ & $14.36^{\mathrm{b}}$ & $4.11^{\mathrm{b}}$ & $0.469^{\mathrm{ab}}$ & $4.61^{\mathrm{bc}}$ & $103.10^{\mathrm{c}}$ & $69.00^{\mathrm{c}}$ & $9.84^{\mathrm{ab}}$ & $21.16^{\mathrm{c}}$ \\
\hline $\mathrm{A}_{7}-\mathrm{AEEO}($ Control $)$ & $15.17^{\mathrm{c}}$ & $4.18^{\mathrm{c}}$ & $0.463^{\mathrm{c}}$ & $4.56^{\mathrm{c}}$ & $106.40^{\mathrm{e}}$ & $33.86^{\mathrm{e}}$ & $26.31^{\mathrm{c}}$ & $39.82^{\mathrm{e}}$ \\
\hline S.Em \pm & 0.05 & 0.03 & 0.002 & 0.05 & 0.66 & 0.31 & 0.43 & 0.15 \\
\hline $\mathrm{CD}$ at $5 \%$ & 0.14 & 0.08 & 0.005 & 0.15 & 1.86 & 0.91 & 1.23 & 0.45 \\
\hline \multicolumn{9}{|l|}{ Varieties (V) } \\
\hline $\mathrm{V}_{1}-$ Thompson Seedless & $14.80^{\mathrm{c}}$ & $3.87^{\mathrm{a}}$ & $0.465^{\mathrm{b}}$ & $5.30^{\mathrm{a}}$ & $99.24^{\mathrm{a}}$ & $67.58^{\mathrm{a}}$ & $11.40^{\mathrm{a}}$ & $21.02^{\mathrm{a}}$ \\
\hline $\mathrm{V}_{2}-2 \mathrm{~A}$ Clone & $14.00^{\mathrm{b}}$ & $4.16^{\mathrm{c}}$ & $0.449^{\mathrm{c}}$ & $4.52^{\mathrm{d}}$ & $105.24^{\mathrm{d}}$ & $64.06^{\mathrm{b}}$ & $12.28^{\mathrm{ab}}$ & $23.66^{\mathrm{b}}$ \\
\hline $\mathrm{V}_{3}-$ Sonaka & $14.99^{\mathrm{d}}$ & $4.10^{c}$ & $0.504^{\mathrm{a}}$ & $4.73^{\mathrm{c}}$ & $102.69^{c}$ & $61.18^{\mathrm{d}}$ & $13.15^{\mathrm{b}}$ & $25.68^{d}$ \\
\hline $\mathrm{V}_{4}-$ Manik Chaman & $14.85^{\mathrm{c}}$ & $4.02^{\mathrm{b}}$ & $0.501^{\mathrm{a}}$ & $5.09^{\mathrm{b}}$ & $100.90^{\mathrm{b}}$ & $67.39^{\mathrm{a}}$ & $11.35^{\mathrm{a}}$ & $21.27^{\mathrm{a}}$ \\
\hline $\mathrm{V}_{5}-$ Merbein Seedless & $13.64^{\mathrm{a}}$ & $4.33^{\mathrm{d}}$ & $0.426^{\mathrm{d}}$ & $3.65^{\mathrm{e}}$ & $106.84^{\mathrm{e}}$ & $63.13^{\mathrm{c}}$ & $12.57^{\mathrm{b}}$ & $24.30^{\mathrm{c}}$ \\
\hline S.Em \pm & 0.04 & 0.02 & 0.004 & 0.04 & 0.56 & 0.26 & 0.36 & 0.13 \\
\hline $\mathrm{CD}$ at $5 \%$ & 0.12 & 0.07 & 0.001 & 0.13 & 1.57 & 0.76 & 1.04 & 0.38 \\
\hline Interactions (A x V) & NS & NS & NS & NS & NS & NS & NS & NS \\
\hline
\end{tabular}

Figures with different alphabet within pre-drying treatments (A) and varieties (V) are significantly different at $\mathrm{p} \leq 0.05$; NS-Not significant.

AA - Ascorbic acid BA - Benzyl adenine 


\section{Raisin wastes (g)}

The raisin wastes (grams decayed raisins from $3 \mathrm{~kg}$ of fresh grapes) was recorded to be lowest in pre-drying treatment AEEO + AA $1000 \mathrm{ppm}\left(\mathrm{A}_{3}\right)$ which may be due to the ascorbic acid play major role to terminate radical chain reactions and protect tissue from damage ultimately leads to maximum yield and minimum wastes of raisins (Farouk, 2011). It was recorded lowest in variety Thompson Seedless than others in the present investigation which might be due to cultivar differences in berry cuticle and skin (Christensen and Peacock, 2000). The interaction effect was not significant with respect to raisin wastes (Table 1).

\section{Percentage of colored raisins}

Raisin color is one of the important qualitative aspects and plays an important role in consumer acceptance. Effect of various concentrations of antioxidants with AEEO as a pre-drying treatment on percentage of green, brown and mixed colored raisins prepared from seedless varieties of grapes are presented in table 1. Significant difference was observed among the pre-drying treatments and varieties on percentage of colored raisins (green, brown and mixed).

\section{Percentage of green colored raisins}

It was recorded to be higher in AEEO with $\mathrm{AA}$ or BA irrespective of their concentration compared with control (i.e. AEEO only). The percentage of green colored raisins increased with the increased concentrations of AA and BA (Table 1) and significantly highest percentage was recorded in $\mathrm{A}_{3}(72.28 \%)$ and lowest in control (33.86\%). There was significant difference found among the seedless grape varieties used for raisin making. Significantly higher percentage of green colored raisins was noted in Thompson seedless $(67.58 \%)$ which was on par with Manik Chaman (67.39\%) and lowest in Sonaka $(61.18 \%)$.

\section{Percentage of brown colored raisins}

The percentage brown colored raisins was observed lowest in pre-treatment AEEO with $\mathrm{AA}$ or BA irrespective of their concentration compared to control. Significantly lowest percentage was recorded in Manik Chaman $(11.35 \%)$ which was comparable with Thompson seedless (11.40\%) and 2A Clone $(12.28 \%)$ whereas highest percentage was found in Sonaka (13.15\%), which was on par with Merbein Seedless (12.57\%) and 2A Clone (12.28\%).

\section{Percentage of mixed colored raisins}

It was evident from table 1 , that the percentage mixed colored raisins are significantly influenced by various concentrations of antioxidants with AEEO as well as varieties and lowest recorded in $\mathrm{A}_{3}$ $(19.08 \%)$ which was on par with $\mathrm{A}_{2}(19.33 \%)$ whereas highest in control $(39.82 \%)$. It decreased with the increase of both AA and BA concentrations with AEEO. The variety Thompson Seedless $(21.02 \%)$ recorded lowest percentage of mixed colored raisins which was on par with Manik Chaman (21.27\%) and maximum percentage was noted in Sonaka $(25.68 \%)$. The interaction effect on percentage of green, brown and mixed colored raisins between various concentrations of antioxidants with AEEO and varieties were not significant.

The pre-drying treatment of grapes with AEEO either with AA and BA effectively reduces brown and mixed colored raisins and correspondingly elevates green colored raisins (Table 1) compared to control due to inhibition of polyphenol oxidase activity (Zhang Yu, 2008). AEEO with AA 1000 ppm 
$\left(\mathrm{A}_{3}\right)$ pre-drying treatment was most effective because the ascorbic acid acts more as an antioxidant than as an enzyme inhibitor due to it reduces browning reactions (Smirnoff, 2000; Rapeanu et al., 2006; Farouk, 2011 and Kendall and Sofos, 2012). Ascorbic acid spray after AEEO $\left(1.5 \% \mathrm{EO}+2.5 \% \quad \mathrm{~K}_{2} \mathrm{CO}_{3}\right)$ pre-treatment minimizes browning and to elevate the overall acceptability in raisins (Sharma et al., 2012). Regarding varieties, Thompson Seedless and Manik Chaman shows the best results with respect to percentage of raisin color might be due to fruits may show large difference in their tendency to brown because of cultivar variation in polyphenol oxidase activity as reported by Sapers and Hicks (1993).

\section{Acknowledgements}

Thanks to University Grants Commission, Government of India for financial assistance and advisory committee, Dr.Y.S.R Horticultural University for technical advice.

\section{References}

Abano, E.E., Sam-Amoah, L.K, Owusu, J and Engmann, F.N. 2013. Effects of ascorbic acid, salt, lemon juice, and honey on drying kinetics and sensory characteristic of dried mango. Croat. J. Food Sci. Technol. 5 (1): 1-10.

Adsule, P.G., Karibasappa, G.S., Banerjee, K. and Mundankar, K. 2008. Status and prospects of raisin industry in India. Acta Horticulture. 785: 507-514.

Adsule, P.G., Sharma, A.K., Banerjee, K. and Karibasappa, G.S. 2012. Raisin industry in India: adoption of good drying practices for safe raisins. National Research Centre for Grapes, Pune, India.

Arzani, K., Sherafaty, A.H. and KousheshSaba, M. 2009. Harvest date and postharvest alkaline treatment effects on quantity and quality of Kashmar, Iran, green raisin. J. Agri. Sci. Technol. 11: 449-456.

Bingol, G., Roberts, J.S, Balaban, M.O and Devres, Y.O. 2012. Effect of dipping temperature and dipping time on drying rate and color change of grapes. Drying Technology. 30: 597-806.

Chadha, K.L., and Shikhamany, S.D. 1999. 'The Grape' Improvement, production and post-harvest Management. Malhotra Publishing House, New Delhi. 54-86.

Christensen, L.P., and Peacock, W.L. 2000. The drying process. Raisin Production Manual. Christensen, L.P. (ed.), University of California, Agricultural and Natural Resources, Oakland. pp. 207-16.

Davey, M.W., Montagu, M.V, Inze', D, Sanmartin, M, Kanellis, A, Smirnoff, N, Benzie, I.J.J, Strain, J.J, Favell, D and Fletcher, J. 2000. Review on Plant Lascorbic acid: chemistry, function, metabolism, bioavailability and effects of processing. Journal of the Science of Food and Agriculture. 80: 825-860.

DFTS, Dried Fruit Technical Services. 2013. International seedless dried grape conf. statistics.

Farouk, S., 2011. Ascorbic acid and $\alpha$ tocopherol minimize salt-induced wheat leaf senescence. Journal of Stress Physiology and Biochemistry. 7 (3): 5879.

Grncarevic, M., 1963. Effect of various dipping treatments on the drying rate of grapes for raisins. American Journal of Enology and Viticulture, 14: 230-234.

Jadhav, P.B., Kakade, D.K, Suryawanshi, G.B, Ruggue, V.C, Chavan, N.D and Kumar, V.V.S. 2010. Effect of different pre-treatments on physico-chemical parameters of raisins prepared from variety Thompson Seedless. Asian Journal of Horticulture. 5 (1): 237-239. 
Kendall, P., and Sofos, J. 2012. Drying Fruits. Food and Nutrition Series: Preparation. Colorado State University Extension, Fort Collins, United States.

Panse, V.G., and Sukhatme, P.V. 1985. Statistical Methods for Agricultural Workers. Indian Council of Agricultural Research, New Delhi, India.

Parpinello, G.P., Heymann, H, Vasquez, S, Cathline, K.A and Fidelibus, M.W. 2012. Grape maturity, yield, quality, sensory properties, and consumer acceptance of Fiesta and Selma Pete dry-on-vine raisins. American Journal of Enology and Viticulture. 63 (2): 212219.

Ramming, D.W., 2009. Water loss from fresh berries of raisin cultivars under controlled drying conditions. American Journal of Enology and Viticulture. 60: 208-214.

Rapeanu, G.A., Loey, C, Smout, $\mathrm{M}$ and Hendrickx. 2006. Biochemical characterization and process stability of polyphenol oxidase extracted from Victoria grape (Vitis vinifera ssp. sativa). Food Chem. 94: 253-261.

Sapers, G.M., and Hicks, K.B. 1993.
Inhibition of enzymatic browning in fruits and vegetables. Quality Factors of Fruits and Vegetables: Chemistry and Technology. Jen, J.J. (Ed.). ACC Symp. Series 405. pp. 29-43.

Sharma, A.K., Ramteke, S.D, Maisha Lahoti and Adsule, P.G. 2012. Effect of ascorbic acid and sodium metabisulphite application on Thompson Seedless grapes bunches during drying. Proceeding of the $5^{\text {th }}$ Indian Horticulture Congress, Ludhiana, India.

Sharma, A.K., Satisha, J. and Somkuwar, R.G. 2013. Raisin quality: the deciding factors. National Research centre for Grapes, Pune, India.

Smirnoff, N., 2000. Ascorbic acid: metabolism and functions of a multifaceted molecule. Curr. Opin. Plant Biol. 3: 229-235.

Winkler, A.J., 1962. General Viticulture. Univ. of California Press: Berkeley, USA. 543-577.

Zhang Yu, 2008. The raisin production and processing in Xinjiang, China. Acta Horticulture. 785: 515-518.

\section{How to cite this article:}

Venkatram, A., A.S. Padmavathamma, D. Vijaya, A. Siva Sankar, K. Manorama and Srinivas Rao, B. 2017. Studies on Various Concentrations of Antioxidants with Alkaline Emulsion of Ethyl Oleate as Pre-Treatment on Rate of Drying, Yield and Colour of Raisins Prepared from Seedless Grape (Vitis vinifera L.). Int.J.Curr.Microbiol.App.Sci. 6(9): 2785-2793. doi: https://doi.org/10.20546/ijcmas.2017.609.343 